\title{
Sports Training and Serum Osteocalcin in Young Athletes of Manipur
}

\author{
Leivon Bellamy Kom*, Ksh Gomti Devi** , L Suresh Roy***, A Jannie \\ Shimray*, Merrycka A Sangma*, Hongprachan Hungyo* \\ * Post Graduates, Regional Institute of Medical Sciences, \\ ** Professor, Regional Institute of Medical Sciences, \\ *** Associate Professor, Regional Institute of Medical Sciences,
}

\begin{abstract}
The purpose of the study is to assess the effect of exercise on bone turnover by measuring serum osteocalcin level in young trained male and female athletes in Manipur and to assess the relationship between serum osteocalcin concentration with age, sex and types of sports of the participants. 50 young athletes (25 women and 25 men) ages ranging from 18 to 21 years were selected from Sports Authority of India, Manipur; the sedentary age-matched non-athletes $(N=10)$ were selected from the general medical student population. Serum osteocalcin was estimated using EDM ${ }^{T M}$ Osteocalcin(1-43/49) Specific ELISA Kit, Epitope Diagnostics, Inc. USA.

Significantly higher mean $\pm S D$ serum osteocalcin concentration was seen in athletes (22.97 \pm 6.36$)$ than nonathletes(11.68 5.60). On comparing the different age groups of athletes ranging from 18yrs to 21 yrs, no significant difference in serum osteocalcin was found. However,male athletes had significantly higher serum osteocalcin (26.07 \pm 5.29$)$ then in female athletes(19.88 \pm 5.89$)$.In hockey players $(N=21)$ serum osteocalcin level was $26.41 \pm 5.40$, runners $(N=18)$ was $19.94 \pm 5.51$ and in cyclist $(N=11)$ it was $21.33 \pm 6.64$.
\end{abstract}

Index Terms: Bone turnover, osteocalcin, osteoblast, sedentary age-matched

\section{Introduction}

A variety of biochemical assays that reflect the activity of osteoblasts (the boneforming cells) and osteoclasts (the bone-resorbing cells) have been developed for clinical use. They have helped increase our understanding of the bone remodeling cycle, the pathogenesis of skeletal disorders, and the response of these disorders to therapy. ${ }^{1-4}$

Osteoblasts are mononuclear cells that attach to bone surfaces and form new bone, most commonly at sites that recently underwent resorption. Markers of bone formation are measured in serum. Some are enzymes or other proteins secreted by osteoblasts, others are byproducts of type I collagen deposition. They are- Total alkaline phosphatase, bone alkaline phosphatase, osteocalcin and procollagen type I propeptides. Whereas osteoclasts are multinucleated cells that resorb bone. ${ }^{5-8}$ Markers of bone resorption are measured in serum or urine. They are- Hydroxyproline, collagen cross-links, pyridinolines and cross-linked telopeptides. ${ }^{9-10}$

Physical activity has been suggested as one of the determinants of bone turnover and to prevent the involutional age related bone loss. Comparisons between trained subjects and untrained controls have demonstrated the influence of exercise on bone turnover. The relatively new development of assays for circulating biochemical markers of bone turnover now allowing us to gain greater mechanistic insight into the effects of factors like exercise and maturation on bone development. ${ }^{11-14}$

Although the majority of newly synthesized osteocalcin is deposited into bone matrix, a small amount can be detected in blood, and it is this characteristic that has led to its current clinical use as a specific index of osteoblastic activity. It is the most abundant and most widely studied of the non-collagenous proteins in bone. It is rapidly cleared from the circulation. Although clearance occurs predominantly in the kidney some metabolism is also seen in the liver but the degradation of the protein is clearly slower. ${ }^{15}$

As the result of previous workers have suggested that serum concentration of osteocalcin may be influenced by the following factors: demographic factors (age and sex) ${ }^{16}$ physiological and clinical factors (exercise, menopause, sample handling, diurnal and day-to-day variability, deficiency of vitamin $\mathrm{k}$ and vitamin D); disease states (osteomalcia, osteoporosis, Paget's disease of bone, hyper- and hypothyroidism, multiple myeloma, liver diseases and diabetes); drugs (glucocorticoids, anticonvulsants, heparin, oral contraceptive use and other drugs affecting bone mass); lifestyle factors (excessive alcohol consumption, vitamin $\mathrm{K}$ and $\mathrm{D}$ deficiency, and physical exercise). ${ }^{17}$ 


\section{Methodology}

A Cross sectional study was conducted in the Department of Physiology, RIMS. 50 young athletes (25 women and 25 men) ages ranging from 18 to 21 years were selected from Sports Authority of India, Manipur ; the sedentary age-matched non-athletes $(\mathrm{N}=10)$ were selected from the general medical student population. Study duration-March 2013 to February 2014 EXCLUSION CRITERIA: Previous history of bone disease, any systemic illnesses , taking drugs affecting bone mass, smokers, excessive alcohol users, abnormal menstruation and pregnancy. Serum osteocalcin was estimated using EDM $^{\mathrm{TM}}$ Osteocalcin(1-43/49) Specific ELISA Kit, Epitope Diagnostics, Inc. USA. Stastical analysis: SPSS-16.0 software, independent T-test, one way ANOVA and $\mathrm{p}$ value $<0.05$ taken as significance. Ethical approval from Institutional Ethical Committee RIMS

\section{Results \\ Table-1}

Comparison Of Mean \pm sd For Age, Height, Weight,bmi And Serum Osteocalcin Between athletes And non-athletes

\begin{tabular}{|l|l|l|l|l|l|}
\hline $\begin{array}{l}\text { Parameter } \\
\text { s }\end{array}$ & $\begin{array}{l}\text { Hockey } \\
\text { Players } \\
(\mathrm{n}=21)\end{array}$ & $\begin{array}{l}\text { Runners } \\
(\mathrm{n}=18)\end{array}$ & $\begin{array}{l}\text { Cyclists } \\
(\mathrm{n}=11)\end{array}$ & $\begin{array}{l}\text { Non- } \\
\text { athletes(n=10) }\end{array}$ \\
\hline Age(Yrs) & $18.90 \pm 1.22$ & $19.33 \pm 0.97$ & $19.82 \pm 1.16$ & $18.80 \pm 0.78$ & NS \\
\hline Height(cm) & $158.45 \pm 4.30$ & $\begin{array}{l}161.14 \pm 6 \\
.23\end{array}$ & $\begin{array}{l}157.85 \pm 4 . \\
36\end{array}$ & $161.40 \pm 5.31$ & NS \\
\hline Weight(Kg) & $53.09 \pm 6.77$ & $56.89 \pm 5.43$ & $54.61 \pm 5.98$ & $56.60 \pm 8.28$ & NS \\
\hline BMI(Kg/m $)$ & $21.23 \pm 1.66$ & $21.86 \pm 1.04$ & $21.83 \pm 1.43$ & $21.87 \pm 3.57$ & NS \\
\hline $\begin{array}{l}\text { Osteocalcin } \\
(\mathrm{ng} / \mathrm{ml})\end{array}$ & $26.41 \pm 5.40$ & $19.94 \pm 5.51$ & $21.33 \pm 6.64$ & $11.68 \pm 5.60$ & 0.000 \\
\hline
\end{tabular}

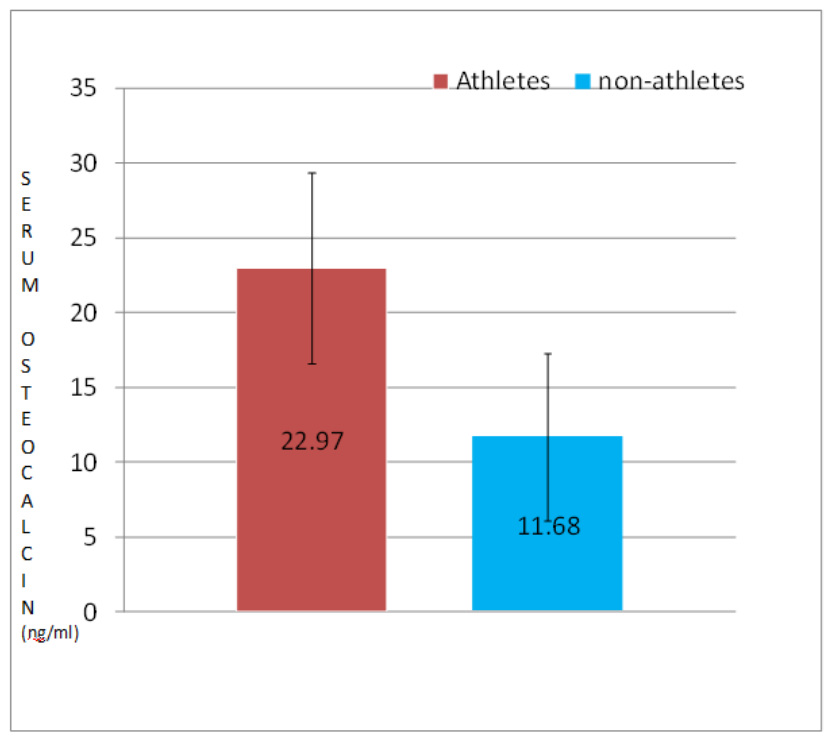

\section{Figure 1 : Mean serum osteocalcin was significantly lower in non-athletes as compared to athletes .P value <0.05}



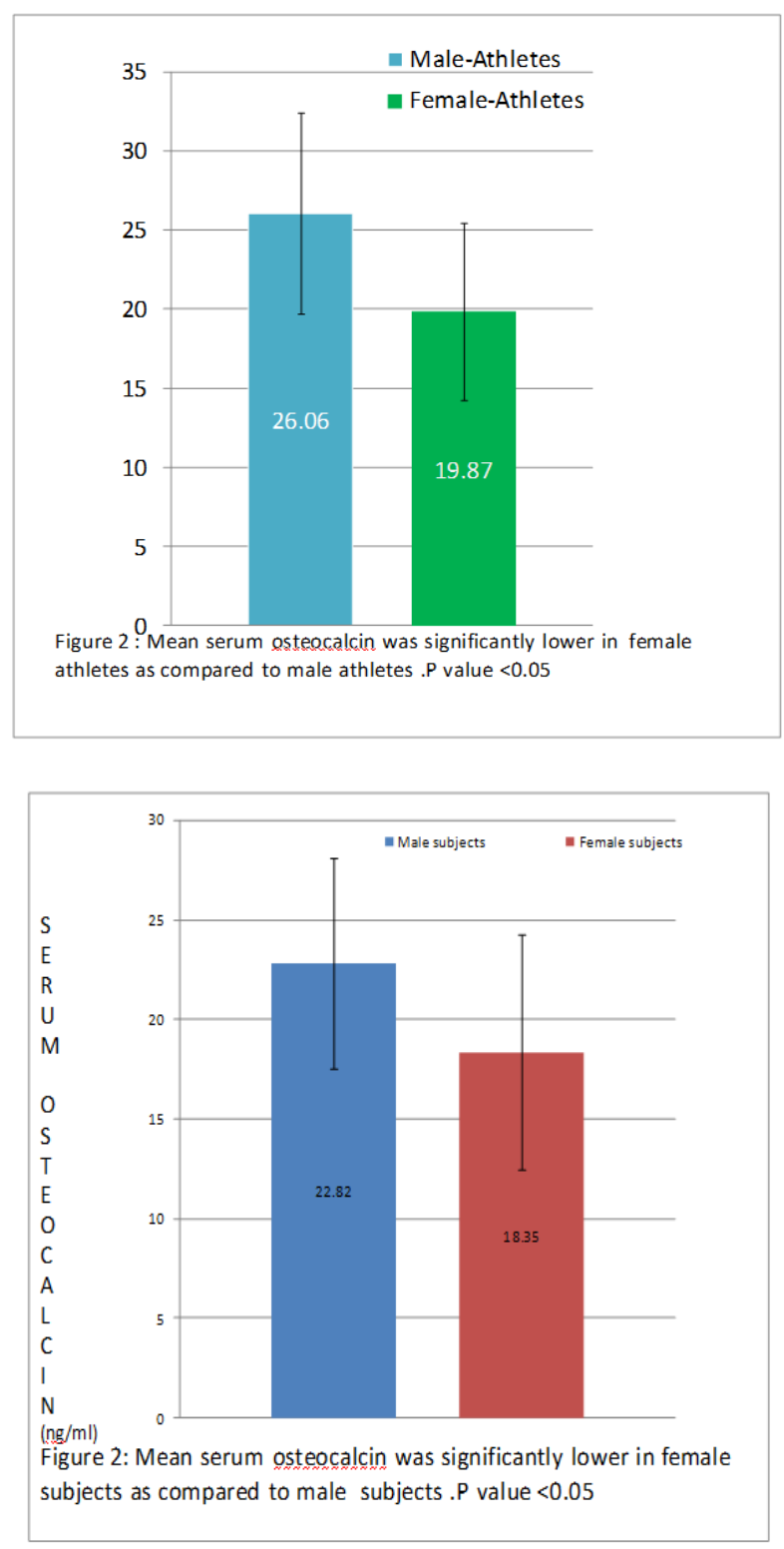

IV. Conclusion

Significantly higher serum osteocalcin concentration was seen in athletes than non-athletes. In hockey players serum osteocalcin level was higher than runners and cyclist. However, male athletes had significantly higher serum osteocalcin than in female athletes. Serum osteocalcin was significantly lower in female subjects as compared to male subjects. The effect of physical activity on bone turnover markers in the growing skeleton has been poorly studied. The present study is particularly important because it examines and establishes certain effects of common physical activities on health. The present data also adds considerable support to the argument that exercise is extremely important and beneficial for high rate of bone turnover, reflected as elevated bone marker.

\section{Acknowledgement}

The presenting author is grateful to his guide Prof. Ksh. Gomti Devi and co-guide Assoc. Prof. L. Suresh Roy, Department of Physiology, RIMS, Manipur for their constant guidance and help throughout the study period. The author also thank Dr. Barun Hanjabam, Department of Sports and Exercise Medicine, Sports Science and Fitness Centre, SAI-NERC, Imphal and to his post-graduate colleagues namely A Jannie Shimray, Merrycka A Sangma and Hongprachan Hungyo for the active participation and help during the study. 
Reference
[1]. Calvo MS, Eyre DR, Gundberg CM. Molecular basis and clinical application of biological markers of bone turnover. Endocr Rev 1996;17:333-68.

[2]. Seibel MJ. Biochemical markers of bone turnover: part I: biochemistry and variability. Clin Biochem Rev 2005; 26:97-122.

[3]. Seibel MJ. Clinical use of markers of bone turnover in metastatic bone disease. Nat Clin Pract Oncol 2005; 2:504-17.

[4]. Seibel MJ. Biochemical markers of bone turnover: part II: clinical applications in the management of osteoporosis. Clin Biochem Rev 2006; 27:123-38.

[5]. Glorieux FH, Travers R, Taylor A. Normative data for iliac bone histomorphometry in growing children. Bone 2000; $26: 103-09$.

[6]. Clarke BL, Ebeling PR, Jones JD. Changes in quantitative bone histomorphometry in aging healthy men. J Clin Endocrinol Metab 1996; 81:2264-70.

[7]. Rucker D, Ezzat S, Diamandi A, Khosravi J, Hanley DA. IGF-I and testosterone levels as predictors of bone mineral density in healthy, community-dwelling men. Clin Endocrinol 2004; 60:491-99.

[8]. Cloos PA, Christgau S. Characterization of aged osteocalcin fragments derived from bone resorption. Clin Lab 2004; 50:585-98.

[9]. Garnero P, Gineyts E, Riou JP, Delmas PD. Assessment of bone resorption with a new marker of collagen degradation in patients with metabolic bone disease. J Clin Endocrinol Metab 1994; 79:780-85.

[10]. Christgau S, Rosenquist C, Alexandersen P. Clinical evaluation of the Serum Cross Laps One Step ELISA, a new assay measuring the serum concentration of bone-derived degradation products of type I collagen C-telopeptides. Clin Chem 1998; 44:2290-300.

[11]. Franck H, Beuker F, Gurk S. The effect of physical activity on bone turnover in young adults. Exp Clin Endocrinol 1991;98(1):426.

[12]. Banfi, Giuseppe, Lombardi, Giovanni, Colombini, Alessandra, et al. Bone Metabolism Markers in Sports Medicine. Sports Med 2010 Aug; 40(8):697-714.

[13]. Maumounl, Simar D, Malatesta D, Caillaud C, Peruchon E, Rossi M, et al. Response of bone metabolism related hormones to single session of strenuous exercise in active elderly subjects. Br J Sports Med 2005; 39: 497-502.

[14]. Eliakim A, Raisz LG, Brasel JA, Cooper DM. Evidence for increased bone formation following a brief endurance-type training intervention in adolescent males. Bone and Miner 1997; 12(10); 1708-13.

[15]. Price PA, Urist MR, Otawara Y. Matrix Gla protein, a new gamma carboxyglutamic acid containing protein which is associated with the organic matrix of bone. Biochem Biophys Res Commun 1983; 117: 765-71.

[16]. Bouillon R, Bex M, Van Herck E, Laureys J, Dooms L, Lesaffre E, et al. Influence of age, sex, and insulin on osteoblast function: osteoblast dysfunction in diabetes mellitus. J Clin Endocrinol Metab 1995;80(4):1194-1202.

[17]. Lee AJ, Hodges S, Eastell R. Measurement of osteocalcin. Ann Clin Biochem 2000;37:432-46. 